STATE OF UTERO-PLACENTAL ANGIOGENESIS IN LATE GESTOSIS

M. O. Shcherbina, O. P. Lipko, I. M. Shcherbina, O. O. Dynnik (Kharkiv, Ukraine)

Kharkiv National Medical University

The investigation of pro-angiogenic and anti-angiogenic growth factors with varying degrees of severity of preeclampsia was done. It was found that placental protein, endoglin and placental growth factor have a predictive value for the diagnosis of preeclampsia, and a significant increase in transforming growth factor is a marker of severe preeclampsia and can be used as a prognostic criterion of her severity.

Key words: preeclampsia; placental proteins; placental growth factor; endoglin; transforming growth factor.

НА ДОПОМОГУ ПРАКТИЧНОМУ ЛІКАРЕВІ

Н. В. ЗОЗУЛЯК , З. В. ЗОЗУЛЯК, В. Є. НЕЙКО, І. Б. РОМАШ , І. Р. РОМАШ I. М. ГАЙОВА' ${ }^{1}$ I. В. ТИМКІВ ${ }^{1}$, М. В. БЛИЗНЮК ${ }^{1}$, H. I. РОМАШ ${ }^{1}$

\title{
ДОСВІД ЗАСТОСУВАННЯ L-АРГІНІНУ У ХВОРИХ НА СТАБІЛЬНУ СТЕНОКАРДІЮ ІІІ ФУНКЦІОНАЛЬНОГО КЛАСУ ІЗ СУПУТНЬОЮ АРТЕРІАЛЬНОЮ ГІПЕРТЕНЗІЕЮ
}

\begin{abstract}
${ }^{1}$ Кафедра пропедевтики внутрішньої медицини (зав. - проф. В. С. Нейко) та ${ }^{2}$ кафедра психіатрії, наркології та медичної психології (зав. - проф. М. І. Винник) ДВНЗ «Івано-Франківський національний медичний університет»;

${ }^{3}$ Терапевтичне відділення Івано-Франківської центральної КМЛ < Romash_Ira@ukr.net>

Метою дослідження було підвищити ефективність лікування хворих на стабільну стенокардію (СС) ІІІ функціонального класу (ФК) з артеріальною гіпертензією (АГ) шляхом комбінаиї базисної терапї̈ з L-аргініном. Обстежено 63 хворих на CС III ФК з АГ. Проводили пробу з реактивною гіперемією, визначали рівні NO і малонового альдегіду. Встановлено, що у хворих L-аргінін значно зменшує прояви ендотеліальної дисфункції, покрашує продукування оксиду азоту і знижує рівень оксидного стресу.
\end{abstract}

Ключові слова: стенокардія; артеріальна гіпертензія; оксид азоту; L-аргінін.

Атеросклероз є основною причиною захворюваності та смертності в розвинених країнах світу. Масштаби цієї проблеми досить значні, від атеросклерозу вмирають більше людей, ніж від усіх видів раку, а це обумовлює значні економічні втрати [2, 6]. Найбільш поширеною формою атеросклерозу є ішемічна хвороба серця (IXC). Особливо небезпечна для таких хворих коморбідна патологія - стабільна стенокардія (CС) та супутня артеріальна гіпертензія (АГ). У патогенезі цих серцево-судинних захворювань важливу роль відіграє знижений рівень оксиду азоту.

Судинорозширювальна здатність ендотелію обумовлюється в основному виділенням оксиду азоту. Крім вазодилатаційної дії, оксид азоту модулює виділення вазоактивних медіаторів, інгібує адгезію лейкоцитів, бере участь у ремоделюванні судинної стінки, пригнічує експресію прозапальних генів, адгезію та агрегацію тромбоцитів $[1,3]$. Пригнічення ендотелійзалежного розслаблення судин при цьому пов'язане з дефіцитом ендотеліального NO, що проявляеться у зниженні (ㄷ Н. В. Зозуляк, 3. В. Зозуляк, В. Є. Нейко, І. Б. Ромаш, І. Р. Ромаш, І. М. Гайова, І. В. Тимків, М. В. Близнюк, Н. I. Ромаш, 2018 
концентрації нітритів і нітратів у плазмі крові. Дефіцит оксиду азоту у хворих на $\mathrm{CC}$ та АГ може бути обумовлений низьким вмістом L-аргініну (субстрат для утворення NO), зниженням активності eNOS, а також руйнуванням або захопленням NO вільними радикалами. Для багатьох експериментальних моделей гіпертензії характерний відносний дефіцит оксиду азоту. При цьому активність NOS може бути підвищеною, а біологічна дія зниженою. Вважають, що зниження доступності NO обумовлено в основному його інактивацією супероксиданіоном, в результаті чого утворюється токсичний пероксинітрит, здатний пошкоджувати ендотелій. У результаті замикається так зване «порочне коло» прогресування серцевосудинної патології $[1,3,4]$. Таким чином, перспективним для корекції ендотеліальної дисфункції у хворих на СС III ФК із супутньою АГ є застосування субстрату для синтезу ендогенного NO - L-аргініну. У багатьох дослідженнях було показано, що L-аргінін здатний поліпшувати ендотелійзалежну вазодилатацію, підвищувати толерантність до фізичних навантажень, а також він має антиоксидантні властивості. Проте немає даних про ефективність L-аргініну у разі поєднаної патології СС ІІІ ФК та АГ.

Мета дослідження - підвищити ефективність лікування хворих на стабільну стенокардію III ФК з артеріальною гіпертензією шляхом застосування базисної терапії в комбінації з донатором оксиду азоту L-аргініном.

Матеріали і методи. Обстежено 63 хворих на СС ІІІ ФК із супутньою АГ, середній вік яких становив $(61,2 \pm 3,8)$ року. У дослідження включено також 20 здорових для контролю норми показників. Усіх хворих розподілено на дві групи: I група базисної терапії (БТ) - 32 хворих, які отримували комплексну терапію антиангінальними та антигіпертензивними засобами; II група (БТ + Т) - 31 хворий, який, крім БТ, отримував додатково препарат Тівортін ${ }^{\circledR}$ (4,2 г L-аргінін) по 100 мл розчину довенно крапельно впродовж 10 днів з наступним переходом на пероральну форму Тівортін ${ }^{\circledR}$ аспартат по 15 мл (3 мірні ложки) 2 рази на добу впродовж наступних 20 днів. Обстеження проводили при госпіталізації до стаціонару та через 1 міс. Ефективність терапії оцінювали за динамікою рівня кінцевих продуктів метаболізму NO (нітритів/нітратів), тесту з реактивною гіперемією за методикою D. Celermajer [5] та визначенням в крові рівня продуктів перекисного окислення ліпідів - малонового альдегіду (МА). Рівень нітритів і нітратів визначали в сироватці крові методом, що грунтується на відновленні нітратів до нітритів з визначенням останніх за допомогою реакції з реактивом Гріса. Судинорухову функцію плечової артерії визначали за допомогою дуплексного ультразвукового сканування шляхом проведення проби з реактивною гіперемією (ендотелійзалежна вазодилатація - ЕЗВД) та нітрогліцерином (ендотелійнезалежна вазодилатація - ЕНВД) з використанням ультразвукового апарату «Logia 500» (Kranzbihler, Німеччина) з лінійним датчиком 7,5 МГц за методикою, описаною D. Celermajer та співавт. [5]. Рівень MA в сироватці крові визначали спектрофотометричним методом.

Результати та їх обговорення. В обох дослідних групах на етапі рандомізації спостерігали знижені порівняно з нормою показники ЕЗВД та ЕНВД. Після проведеного лікування показник ЕЗВД достовірно збільшився в групі БТ на 41,7 \% ( $<<0,01)$, в групі БТ + Т - на $69,1 \%(\mathrm{P}<0,001)$; таблиця.

Таким чином, L-аргінін здатний значно покращувати ЕЗВД, імовірно, за рахунок постачання субстрату для синтезу оксиду азоту, а також завдяки антиоксидантним властивостям, що перешкоджає надлишковому утворенню токсичного пероксинітриту в умовах підвищеного оксидного стресу. ЕНВД у групі БТ достовірно знижувалась, а в групі БТ + Т змінювалась недостовірно, що може свідчити про зниження чутливості до нітратів у групі БТ. Досліджуючи показник NO, можемо відмітити, що у хворих обох груп був знижений рівень загального NO. Після проведеного лікування в основній групі цей показник достовірно збільшився на $18,1 \%$ ( даного показника. Рівень МА також достовірно знизився у групі БТ + Т, тоді як у групі БТ достовірних змін не відмічали. 
Динаміка показників функції ендотелію у хворих на стабільну стенокардію

III функціонального класу із супутньою артеріальною гіпертензією $(M \pm m)$

\begin{tabular}{|c|c|c|c|c|c|}
\hline \multirow{2}{*}{ Показник } & \multirow{2}{*}{$\begin{array}{l}\text { Здорові } \\
(n=20)\end{array}$} & \multicolumn{2}{|c|}{$\begin{array}{c}\text { Базисна терапія } \\
(n=32)\end{array}$} & \multicolumn{2}{|c|}{$\begin{array}{l}\text { Базисна терапія + } \\
\text { L-аргінін }(n=31)\end{array}$} \\
\hline & & до лікування & через 1 міс & до лікування & через 1 міс \\
\hline ЕЗВД, \% & $10,47 \pm 0,15$ & $3,67 \pm 0,21$ & $\begin{array}{c}5,20 \pm 0,37 \\
\mathrm{P}<0,01\end{array}$ & $3,79 \pm 0,19$ & $\begin{array}{c}6,41 \pm 0,49 \\
\mathrm{P}<0,001\end{array}$ \\
\hline ЕНВД, \% & $20,49 \pm 0,14$ & $17,39 \pm 0,23$ & $\begin{array}{c}16,43 \pm 0,30 \\
P<0,05\end{array}$ & $17,70 \pm 0,32$ & $\begin{array}{c}18,57 \pm 0,3 \\
P>0,05\end{array}$ \\
\hline $\begin{array}{l}\text { Загальний NO, } \\
\text { мкмоль/л }\end{array}$ & $38,82 \pm 0,38$ & $31,51 \pm 0,93$ & $\begin{array}{c}32,93 \pm 0,84 \\
P>0,05\end{array}$ & $31,20 \pm 0,88$ & $\begin{array}{c}36,90 \pm 0,76 \\
\mathrm{P}<0,001\end{array}$ \\
\hline МА, нмоль/мл & $3,69 \pm 0,04$ & $5,77 \pm 0,16$ & $\begin{array}{c}5,41 \pm 0,15 \\
\mathrm{P}>0,05 \\
\end{array}$ & $5,73 \pm 0,18$ & $\begin{array}{c}5,21 \pm 0,19 \\
\mathrm{P}<0,05 \\
\end{array}$ \\
\hline
\end{tabular}

$\mathrm{P}$ - достовірність різниці даних порівняно з величинами до лікування.

Висновки. 1. У хворих на СС III ФК із супутньою АГ через 1 міс БТ спостерігається зниження чутливості до нітратів, а також виражена ендотеліальна дисфункція (знижені показники ЕЗВД, ЕНВД, NO). 2. Використання L-аргініну як терапії супроводу дозволяє покращити показники ендотеліальної функції. 3. L-аргінін знижує рівень оксидного стресу, що забезпечує зниження деактивації ендогенного NO.

$$
\text { С пи сок літ ератури }
$$

1. Бабушкина A. B. L-аргинин с точки зрения доказательной медицины // Укр. мед. часопис. - 2009. - № 74 (XI/XII). - C. 43-48.

2. Катеренчук I. П. Шляхи медикаментозної корекції NO-залежної кардіоваскулярної патології в пацієнтів літнього й похилого віку // Практ. лікар. - 2016. - № 3. - С. 38-44.

3. Марков X. M. L-аргинин - оксид азота в терапии болезней сердца и сосудов // Кардиология. - 2005. - № 6. - С. 87-95.

4. Слободський В. А. Досвід застосування препарату Тівортін ${ }^{\circledR}$ аспартат при лікуванні пацієнтів зі стабільною стенокардією // Укр. мед. часопис. - 2009. Вип. 73, № 5. - С. 40-43.

5. Celermajer D. S., Sorensen K. E., Gooch V. M. et al. Non-invasive detection of endothelial dysfunction in children and adults at risk of atherosclerosis // Lancet. -1992. - Vol. 340, N 7. P. $1111-1115$.

6. Stocker R., Keaney J. F. Role of oxidative modifications in atherosclerosis // Physiol. Rev. 2004. - Vol. 84. - P. 201-209.

\section{ОПЫТ ПРИМЕНЕНИЯ L-АРГИНИНА У БОЛЬНЫХ СТАБИЛЬНОЙ СТЕНОКАРДИЕЙ ІІІ ФУНКЦИОНАЛЬНОГО КЛАССА С СОПУТСТВУЮЩЕЙ АРТЕРИАЛЬНОЙ ГИПЕРТЕНЗИЕЙ}

Н. В. Зозуляк, З. В. Зозуляк, В. Е. Нейко, И. Б. Ромаш, И. Р. Ромаш, И. М. Гайова, И. В. Тымкив, М. В. Блызнюк, Н. И. Ромаш (Ивано-Франковск)

Целью исследования было повысить эффективность лечения больных стабильной стенокардией (CC) III функционального класса (ФК) с артериальной гипертензией (АГ) путём комбинации базисной терапии с L-аргинином. Обследовано 63 больных CC III ФК с АГ. Проводили пробу с реактивной гиперемией, определяли уровни NO и малонового альдегида. Установлено, что у больных L-аргинин значительно уменьшает проявления эндотелиальной дисфункции, улучшает продукцию оксида азота и снижает уровень оксидного стресса.

Ключевые слова: стабильная стенокардия; артериальная гипертензия; оксид азота; L-аргинин. 
EXPERIENCE OF L-ARGININE ADMINISTRATION IN PATIENTS WITH STABLE ANGINA FC III WITH CONCOMITANT HYPERTENSION

N. V. Zozuliak', Z. V. Zozuliak³, V. Ye. Neiko', I. B. Romash', I. R. Romash', I. M. Gayova1, I. V. Tymkiv', M. V. Blyzniuk¹, N. I. Romash ${ }^{1}$ (Ivano-Frankivsk, Ukraine)

1, ${ }^{2}$ SHEE “Ivano-Frankivsk National Medical University”;

${ }^{3}$ Ivano-Frankivsk Central Clinical Hospital. Therapeutic Department No. 2

The aim of the study was to improve treatment of patients with Stable Angina FC III with concomitant Hypertension through a combination of basic therapy with L-arginine. The study involved 63 patients with Stable Angina FC III with Hypertension. In the clinic was made the test with reactive hyperemia, were measured levels of $\mathrm{NO}$ and malonic aldehyde. It was found that in studied patients L-arginine reduces signs of endothelial dysfunction, improves production of nitric oxide and lowers oxidative stress.

Key words: Stable Angina; Hypertension; nitric oxide; L-arginine.

УДК [616.13/.14-031.62]:616.16]-002.18-005.6-002.77]-091.8-036.1 DOI 10.31640/JVD.5-6.2018(16) Надійшла 18.09.2017

V. K. KAZYMYRKO', O. N. NADASHKEVICH', V. E. KLOCHKO', L. M. IVANITSKA', T. S. SILANTIEVA', A. G. DUBKOVA ${ }^{1}$

\section{STATE OF SMALL VESSELS \\ (INTRA-PARENCHYMAL ARTERIES, ARTERIOLES, CAPILLARIES, VENULES) IN PATIENTS WITH THROMBOANGIITIS OBLITERANS}

${ }^{1}$ Shupyk National Medical Academy of Postgraduate Education; ${ }^{2}$ City Hospital No1, Bila Tserkva, Kyiv oblast', ${ }^{3}$ Danylo Halytskyi Lviv National Medical University <liliyaivanitska@gmail.com>

The paperaddresses pathological findings in small blood vessels (parenchymal arteries, arterioles, capillaries, venules) of patients with thromboangiitis obliterans. Based on the findings of microcirculation condition in the brain, myocardium, lungs, liver, spleen, kidneys and muscles, we find it advisable to include thromboangiitis obliterans into the Nomenclature of Systemic Vasculitides.

Key words: thromboangiitis obliterans; small vessels; parenchymal arteries; arterioles; capillaries and venules.

In accordance with the ICD-10, thromboangiitis obliterans (Winiwarter - Buerger disease) refers to a group of systemic disorders of connective tissue. It was not included into the 2012 version of the Nomenclature of Systemic Vasculitides [11, 14]. Obviously, the decision was made under the influence of some researchers [3, 18] who consider an acute thrombotic process to be an initial event followed by inflammation of vessel walls. Having analysed the relevant publications [6], we did not find the evidence sound enough to accept this point of view even given the fact that against the background of the gradual disease progression there can occur a severe artery blockage by thrombus, which results in the associated clinical presentation. Some other authors also doubt the leading role of thrombosis in thromboangiitis obliterans (TAO) genesis [17, 25].

This disease primarily affects small arteries and veins of the lower extremities, leading to their occlusion. The causes of the disease, except for the role of smoking, and the pathogenesis remain unknown to date [16]. Productive (proliferative) endo-, meso and periphlebitis occur in the veins of the lower extremities. Similar events are seen in the arteries of the lower extremities. The vessels take the shape of fibrous strands; thickening of the walls in this case is of segmental character. The nature of the morphological changes in the blood vessels depends on the stage of the pathological process [19], as shown in Table 1. 